\title{
Needs Analysis: Development of Web-Based Learning Media on Chemical Bond Concepts
}

\author{
Nurhafidhah ${ }^{1}$, Hasby ${ }^{1 *}$, Muhammad Nazar ${ }^{2}$ and Sirry Alvina ${ }^{3}$ \\ ${ }^{1}$ Department of Chemical Education, Samudra University, Langsa, 24415, Aceh, Indonesia \\ ${ }^{2}$ Department of Chemical Education, Syiah Kuala University, 23111, Aceh, Indonesia \\ ${ }^{3}$ Department of Chemical Education, Malikusshaleh University, Aceh, Indonesia \\ *E-mail: Hasby@unsam.com.id
}

Received: 23 November 2021; Accepted: 18 December 2021; Published: 31 December 2021

\begin{abstract}
The study aims to explain the need for developing web-based learning media on chemical bonding concepts. This research is descriptive research with a survey method. The sample of this research is the teacher of chemistry subject who teaches chemical bonding concepts at Senior High School in Langsa city. Data collection techniques using questionnaires, interviews, and documentation. The data collected is data on needs on aspects of teacher readiness, student needs, and support. Data analysis uses descriptive qualitative and quantitative descriptive analysis techniques. The results showed that teachers of chemistry subjects at Senior High School in Langsa City had the readiness to use web-based learning media that would be developed. Based on the teacher's response, the development of web-based learning media on chemical bonding material is strongly needed by teachers and students. The support of facilities and human resources at Senior High School in Langsa City on web-based learning media apply is adequate. These results concluded that the development of web-based learning media on chemical bonding material is strongly needed in chemistry lessons at senior high school in Langsa city.
\end{abstract}

Keywords: chemical bond, media, web-based learning

DOI: http://dx.doi.org/10.15575/jtk.v6i2.10288

\section{Introduction}

The use of media as a companion in the learning process is increasingly needed to overcome problems that arise due to limited time, place, and other facilities. The fast and rapid growth of technology and information provides online teaching and learning becomes possible for education (Pandia et al., 2021)

The use of media can build students' mindsets that were previously abstract into the concrete. Through the development of online learning media, students can be guided in learning about concepts and can improve students' learning abilities (Kalatting et al., 2015). Sahudra, et al. (2020) state that the development of information technology that can process, package, display, and spread learning information both audiovisually and multimedia, for example by developing ELearning to support the learning process, so learning is not only focused on learning resources, media, and other tools. In addition, learning using e-learning can stimulate students to learn independently and be actively involved in learning. This is following the concept of learning based on curriculum 2013. The learning process is on the students, so students are required to be active in the learning process (Hamidah, 2019).

Based on the results of interviews with several chemistry teachers at Langsa City Senior High School, most of the teachers carried out online learning through the Zoom Meeting application, Google Classroom, Google Meet, 
and Ruang Guru. However, the implementation of learning experienced many difficulties, including inadequate internet signal network to conduct video conferences, difficulty controlling interaction with students, lack of student knowledge about how to use media, and limited study quota assistance (Radovan \& Perdih, 2018).

The use of web-based media can overcome this deficiency in online learning. Compared to other online learning media, web-based learning can be tailored to the needs and does not require special skills to use it. Although learning is not carried out online, web-based learning media can still be used in learning in the current era of the digital revolution. The development of web-based learning media has been carried out by several previous researchers, such as in learning chemistry (Husrah et al., 2020; Oktaviani et al., 2020; Nabuasa et al., 2020), mathematics (Irianti \& Wicaksono, 2021; Harahap \& Fauzi, 2017; Ahsan et al., 2021), physics (Kalatting et al., 2015; Amri \& Wiyono, 2015), computers (Sari \& Suswanto, 2017), and science (Lin \& YingWei $\mathrm{Wu}, 2016)$. Although the available media have advantages and are sufficient, media development continues to be carried out according to user needs and goals. However, the readiness of the user's initial capabilities is very important to know. so that the use of web media becomes optimal and sustainable.

In developing a learning application, analysis needs are needed to produce good and appropriate applications with user expectations (Nazar et al., 2020). The development of web-based learning media on chemical bonding material is needed because of the abstract nature of chemical bonding material, requiring multimedia in the delivery process. The objective of this research is to describe the needs and supporting factors for the development of web-based learning media. There is no web media on chemical bonding materials used by teachers and students at Senior High School in Langsa City. It is hoped that the results of this study will be taken into consideration in developing webbased learning media. Based on the background of the problem that has been described above, the researchers decided to conduct a needs analysis for the development of web-based learning media on chemical bonding material at Langsa City Senior High School.

\section{Research Method}

This type of research is descriptive research with a survey method. The research population is all the teachers of chemistry subjects at Senior High School in Langsa city. The research sample was selected by a random technique. The sample of this research is the teacher of chemistry subject who teaches chemical bonding material at Senior High School in Langsa city. Data was collected through literature studies and field studies.

Literature studies related to the analysis of documents and other materials that support the development of web media. Field studies were conducted to collect information related to the needs and supporting factors for the development of web-based learning media, including teacher readiness, student needs, and school support. The data needed in the field research was obtained through interview and observation questionnaire techniques. As a source of data for this field study, 15 teachers of chemistry subjects were used. guidelines for data collection using interviews, questionnaires, and direct observation. Analysis of research data using descriptive analysis.

\section{Result and Discussion}

The results of the study were obtained from the answers to questionnaires, observations, and interviews. The form of data on the needs of developing web-based learning media in Langsa city, including teacher readiness, student needs, and school support.

\subsection{Teacher readiness}

The readiness of teachers to use ICT media needs to be identified so that teachers and students have no difficulty using the webbased media that will be developed. In addition, knowing the teacher's readiness 
becomes advice and input in developing webbased media according to user needs. According to Nursamsu and Kusnafizal (2017), the existence of a multimedia computer will make it easier for teachers to generate student motivation and improve student achievement. It is also expected to make it easier for students to receive subject matter so that they can learn easily.

Based on the teacher's answer to the questionnaire instrument, it is known that the teacher has used ICT media in chemistry learning (Figure 1). ICT-based learning media that have been implemented include Microsoft Power Point, Video, Flash, Zoom, Website, Quizizz, Canva, Google Classroom, Elearning Ispring, Quipper, Zenius, Ruang Guru, and Rumah Belajar. According to Mweene and Muzaza (2020), It is better if an educator can choose and use learning media properly so that students are more enthusiastic in participating in the learning that is delivered and increase learning motivation in students.

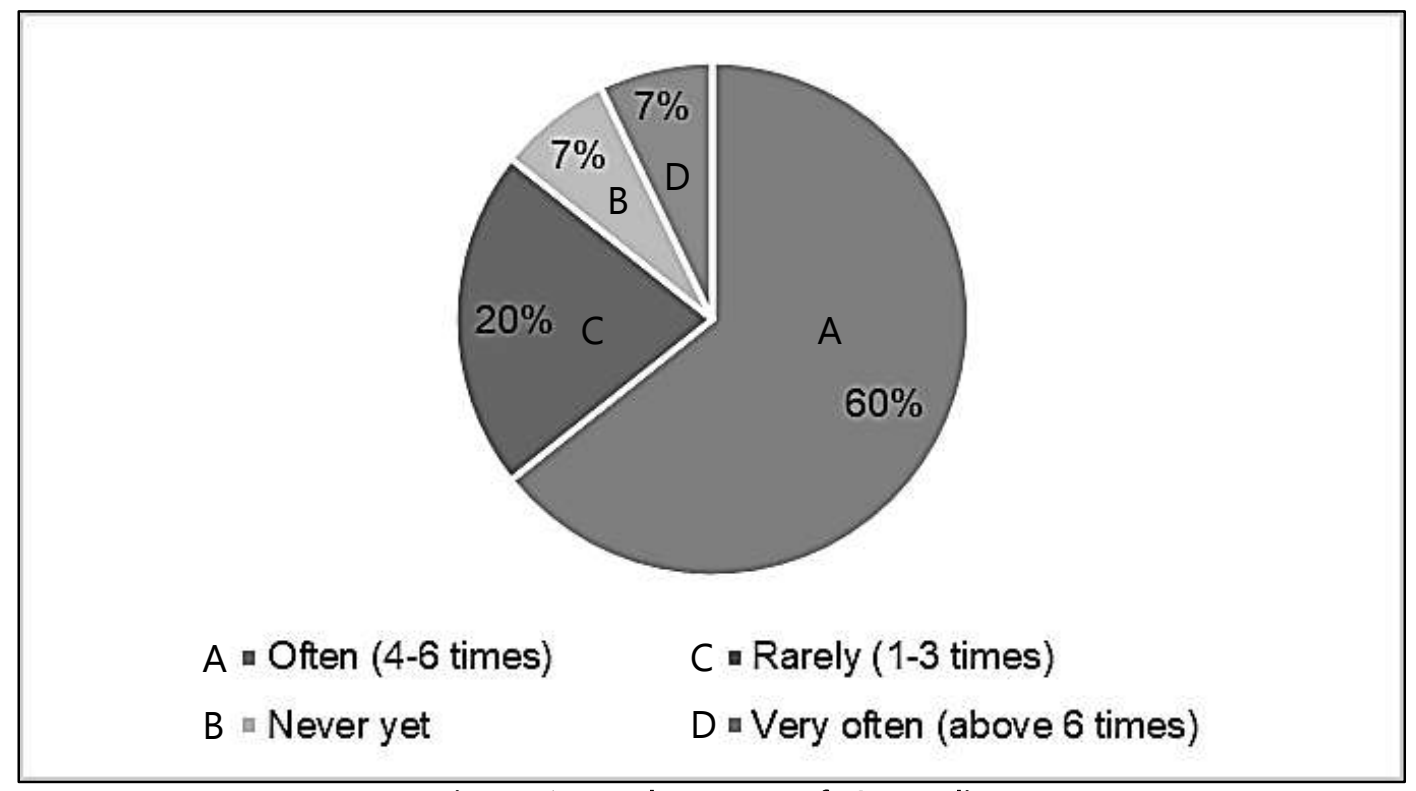

Figure 1. Teacher's Use of ICT Media

Teachers also apply learning models that support the use of ICT media, such as computer-based learning, E-learning, webbased learning, and Blended learning. This shows that the teacher of chemistry subjects at Senior High Schools Langsa city is no stranger to web-based learning media, so the media developed has great potential to be used in chemistry learning. The learning topics that teachers have taught using ICT media include Basic laws of chemistry and stoichiometry, atomic structure, periodic table systems and properties of elements, chemical bonds, thermochemistry, chemical kinetics, chemical equilibrium, the chemistry of solutions (acid- base, hydrolysis, buffer and chemical properties). colligative), Redox and electrochemical reactions, Chemical elements, Colloids, Hydrocarbons, Macromolecules (carbohydrates, proteins, and fats). Almost all chemistry subject matter is an abstract concept. According to Nazar et al. (2020) Since the understanding of abstract concepts is crucial for students, involving computer software to guide students in learning, thus become very important and helpful. Teacher responses to other questions related to the development of web-based learning media can be seen in Figure 2. 


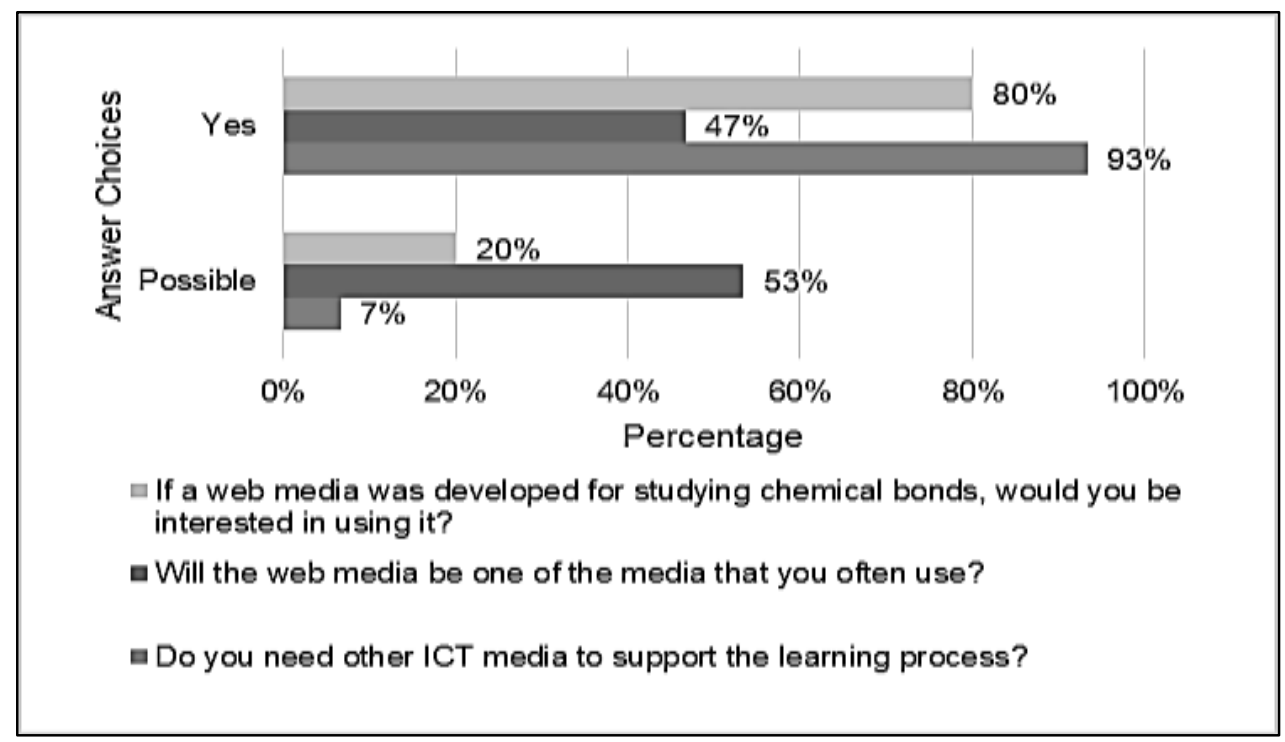

Figure 2. Teacher's Interest in Web-Based Learning Media

Education does not lag behind the development of science and technology, adjustments are needed, especially about teaching factors in schools. One of these factors is learning media that need to be studied and mastered by teachers/prospective teachers so that they can deliver the subject matter to students efficiently and effectively (Mweene \& Muzaza, 2020). Therefore, based on the readiness of Senior high school teachers in Langsa City, web-based learning media on chemical bonding material at Langsa City Senior High School can be developed.

\subsection{Student Needs}

Needs analysis is not only carried out to determine the readiness of teachers but also the needs of students as learning objects. Through several questionnaires, questions obtained data on the needs of students through teachers who interact directly with students. $73 \%$ of teachers think that students show a good response to ICT media that have been used (Figure 3). Nursamsu and Kusnafizal (2017) stated that the use of learning media using computer information technology makes students active in learning. This statement is one of the reasons for the good response of students to the use of ICT media.

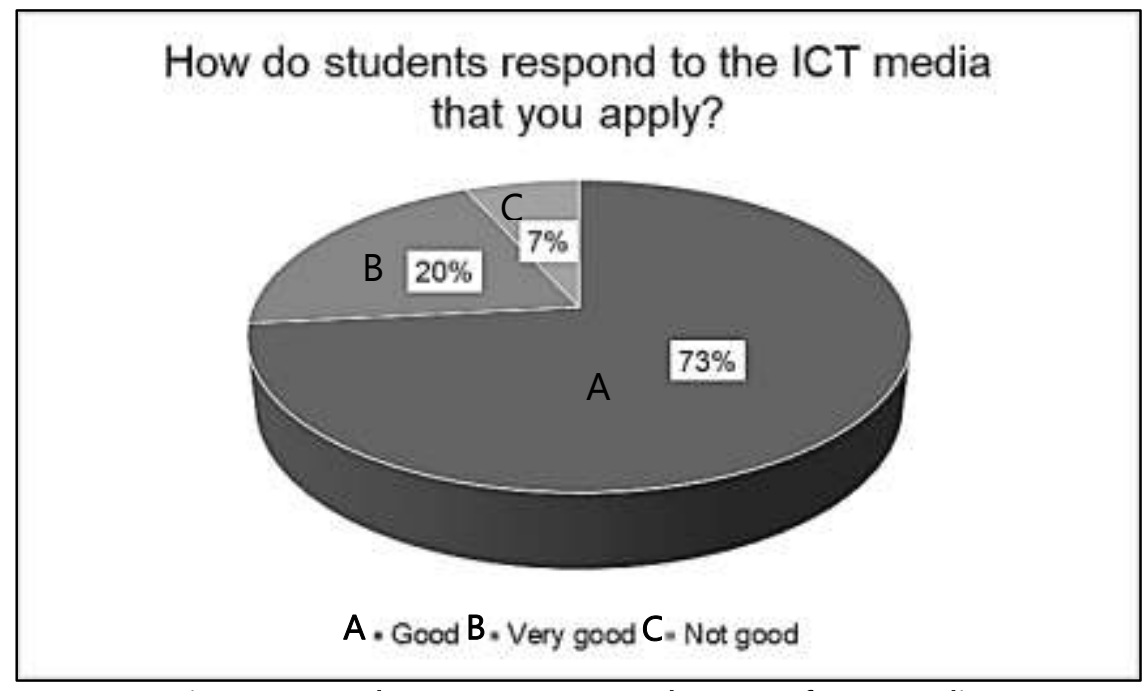

Figure 3. Student Responses to the Use of ICT Media 
One of the ICT media is web media. Many web media have been developed into Schoology media. Schoology learning is software that is used to create web-based online learning materials and manage learning activities and their results (Sahudra et al., 2020). Schoology media is one of the media that has been used by students at senior high school in Langsa City. The ICT media that have been run/used by students include Microsoft Power Point, Video, Flash, Web, Classroom, Ruang Guru, Rumah Belajar. This shows that students have the initial ability to run and use web-based learning media that will be developed. Furthermore, according to the teacher's perception, the characteristics and types of ICT media that students expect are as follows 1 ) the form of ppt media, animation, video, elearning such as google classroom, and website; 2) media that is easy to understand and easy to use; 3) media with good display and helps to understand the concept; 4) the media is easily accessible to students and interesting; and the media displays quizzes with assessments such as the spin quiz method.
In the teacher's opinion, the obstacles for students to use ICT media are: not all students have the ability to use media, lack of internet quota, unstable internet connection, power outages, and time problems. However, nine out of 15 teachers stated that students would be interested in using web media which was developed in chemical bonding materials

\subsection{School Support}

The support referred to in this study is the availability of school facilities, facilities, and infrastructure as well as human resources who can use ICT media, especially the web. Information on school facilities was obtained from direct observations of the sample schools. All schools have technological equipment such as computers, infocus, wifi, and others. Based on the answers to the questionnaire, eight out of 15 teachers stated that the internet connection conditions in schools were adequate (Figure 4). Internet access in schools has been used for school administration, learning, and assessment purposes.

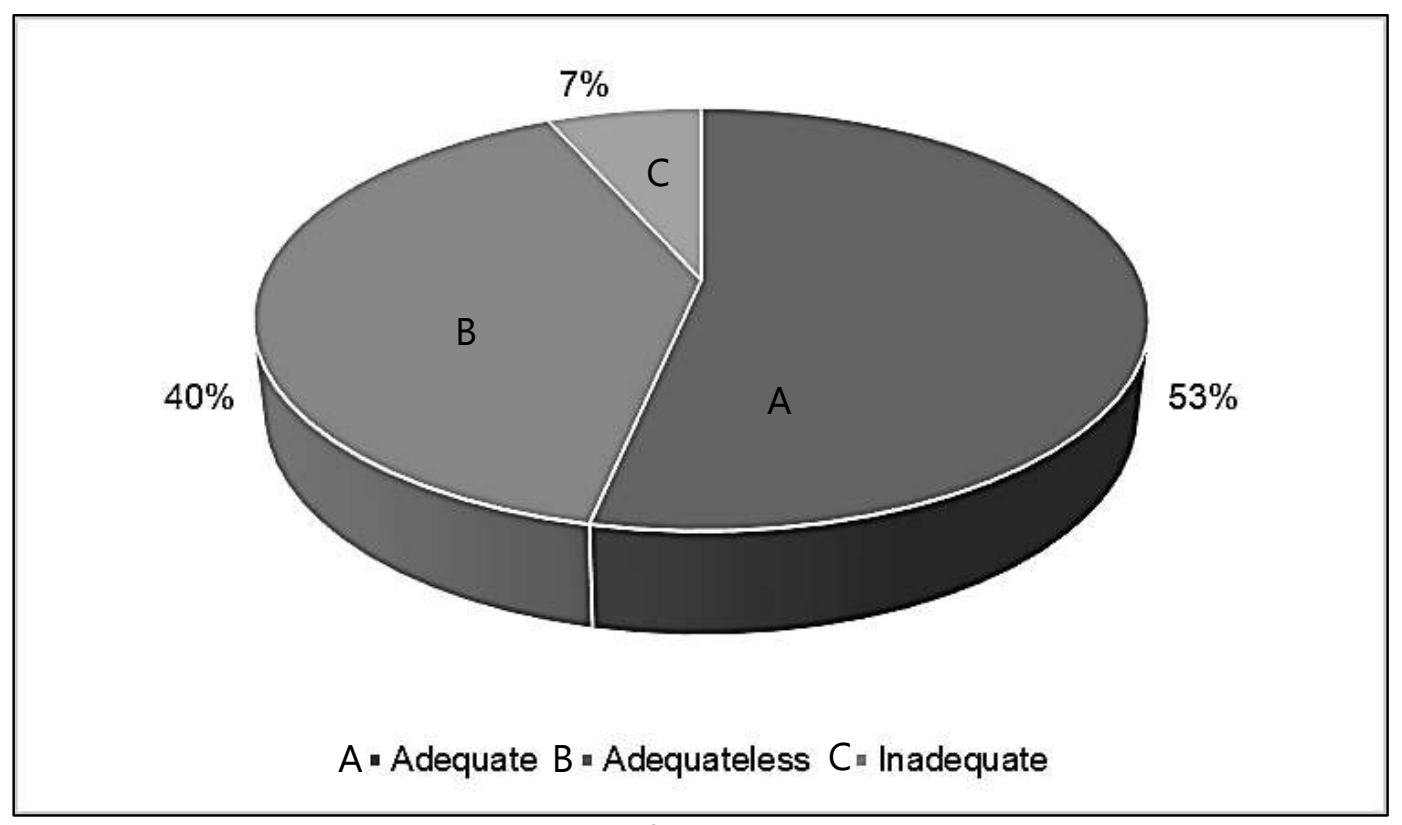

Figure 4. Condition of Internet Facilities at School

School support in the aspect of human resources is known from the proportion of teachers who can use ICT media based on teacher responses (Figure 5) 


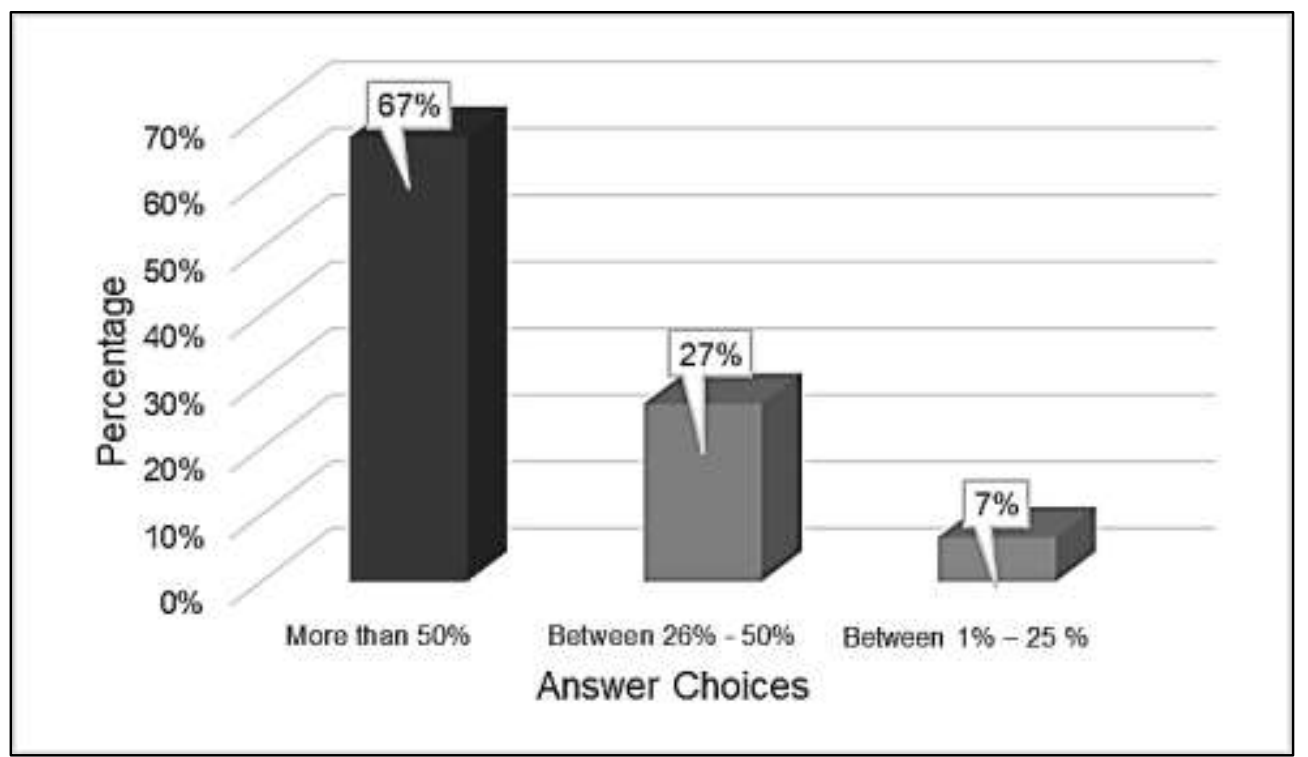

Figure 5. Percentage of Teachers who Master the Use of ICT Media

\section{Conclusion}

Based on the results of the research, it can be concluded that the development of chemistry learning based on web-based learning technology on chemical bonding material is strongly needed at Senior high school in Langsa city. Because there is no web-based learning media on chemical bonding material used by teachers and students at Senior High School in Langsa city. Although already many available websites online but not as needed teachers and students at Senior High School in Langsa city.

\section{Acknowledgments}

We acknowledge the LPPM of Universitas Samudra for funding this research through the Research of excellent base (PDU) 2021 scheme.

\section{References}

Hamidah, N. (2019). Pengembangan Media Pembelajaran Berbasis Web Dengan Model Discovery Learning Pada Mata Pelajaran Sistem Komputer Untuk Meningkatkan Pemahaman Siswa SMK Kelas XI. Skripsi. Bandung: Universitas Pendidikan Indonesia. Retrieved from http://repository.upi.edu/48200/
Husrah, I., Erna, M., \& Rasmiwetti. 2020. Effectiveness of Chemistry Media Learning Based On Autoplay Media Studio 8.0 To Improve Students' Collaborative Character In Acid-Base Material At SMAN 6 Pekanbaru. International Journal of Educational Best Practices (IJEBP), 4 (2), 33-47, https://10.32581/ijebp.v4n2.p33-47

Irianti, N. P., \& Wicaksono, A. A. (2021). Pengembangan Media E-Learning Berbasis Web Untuk Mata Pelajaran Matematika. Jurnal Math Education Nusantara, 4(1), 1-9. https://doi.org/10.32696/jmn.v4i1.117

Kalatting, S., Serevina, V., dan Astra, I.M. (2015). Pengembangan Media Pembelajaran Fisika Berbasis Web Menggunakan Pendekatan Guided Discovery Learning. Jurnal Penelitian \& Pengembangan Pendidikan Fisika, 1(1): 1-8. https://doi.org/10.21009/1.01101

Mweene, P. \& Muzaza, G. (2020). Implementation of Interactive Learning Media on Chemical Materials. Journal Educational Verkenning, 1 (1), 008-013. https://doi.org/10.48173/jev.v1i1.24 
Nursamsu dan Kusnafizal, T. 2017. Implementasi Pembelajaran Berbasis ICT (Information and Communication Technology) Sebagai Alat Bantu Komputer Multimedia untuk Meningkatkan Kompetensi Guru Serta Prestasi Belajar Siswa. Jurnal Pendidikan Biologi, 6 (3), 1-5. https://doi.org/10.24114/jpb.v6i3.8038

Nazar, M., Zulfadli., Oktarina, A., and Puspita, K. (2020). Pengembangan Aplikasi Pembelajaran Interaktif Berbasis Android Untuk Membantu Mahasiswa Dalam Mempelajari Materi Larutan Elektrolit Dan Nonelektrolit. Jurnal Pendidikan Sains Indonesia (Indonesian Journal of Science Education), 8 (1), 39-54. https://doi.org/10.24815/jpsi.v8i1.160 47

Nazar, M., Aisyi, R., Rahmayani, R F I., Hanum, L. , Rusman, R., Puspita, K., and M Hidayat. (2020). Development of Augmented Reality application for learning the concept of molecular geometry. IOP Conf. Series: Journal of Physics: Conf. Series 1460 (2020) 012083. https://doi.org/10.1088/17426596/1460/1/012083

Nabuasa, D. A., Supardi, K.I., and Sumarti, S.S. (2020). Development of the Website based Chemistry Learning Integrated Evaluation To Measure Students Learning Interest In Colloids Material. Journal of Innovative Science Education, 9(1), 12-18. https://DOI 10.15294/jise.v8i1. 31215

Nursamsu \& Kusnafizal, T. (2017). Pemanfaatan Media Pembelajaran ICT Sebagai Kegiatan Pembelajaran Siswa di SMP Negeri Aceh Tamiang, Jurnal IPA dan Pembelajaran IPA (JIPI), 1(2), 165-170.

https://doi.org/10.24815/jipi.v1i2.9691
Oktaviani, O., Cahyana, U., \& Purwanto, A. 2020. Development Of Web-Based Chemical Learning Media In Coloid System Topic Using Wordpress. Jurnal Tadris Kimiya, 5 (1), 104-117, https://doi.org/10.15575/jtk.v5i1.7425

Pandia, E. S,. Nurmasyitah., Nursamsu, and Ariska, R. N. (2021). The Effect of the use of smartphone as an e-learning tool to Students' performance. The $4^{\text {th }}$ international conference on mathematics and science education (ICOMSE) 2020, AIP Conference Proceeding 2330, 060019 (2021); https://doi.org/10.1063/5.0043370

Radovan, M., \& Perdih, M. (2018). Analysing Accessibility, Usability and Readability of Web-based Learning Materials Case study of e-learning portals in Slovenia. Journal of E-Learning and Knowledge Society, 14(1). https:// doi.org/10.20368/1971-8829/1389

Sahudra, TM, Nurmasytah, N., and Nursamsu, N. (2020). Application of E-Learning Learning Media with Schoology on Character Education, Budapest International Research and Critics Institute-Journal (BIRCI-Journal), 3 (3), 2255-2261. 